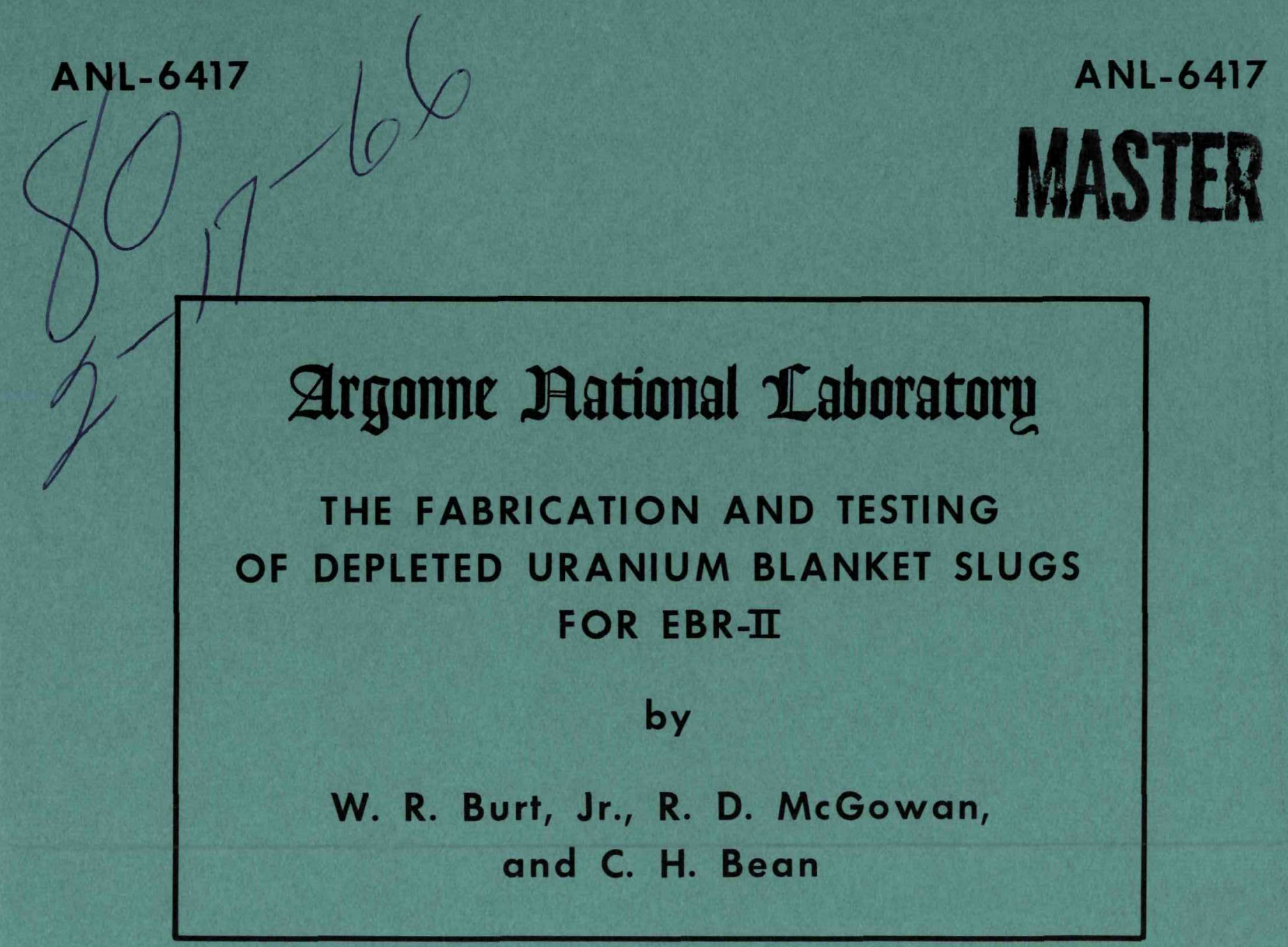

RELEASED FOR ANNOUNCEMENT

IN MUCIEAR SCIDNCE ABSTRACTS 


\section{DISCLAIMER}

This report was prepared as an account of work sponsored by an agency of the United States Government. Neither the United States Government nor any agency Thereof, nor any of their employees, makes any warranty, express or implied, or assumes any legal liability or responsibility for the accuracy, completeness, or usefulness of any information, apparatus, product, or process disclosed, or represents that its use would not infringe privately owned rights. Reference herein to any specific commercial product, process, or service by trade name, trademark, manufacturer, or otherwise does not necessarily constitute or imply its endorsement, recommendation, or favoring by the United States Government or any agency thereof. The views and opinions of authors expressed herein do not necessarily state or reflect those of the United States Government or any agency thereof. 


\section{DISCLAIMER}

Portions of this document may be illegible in electronic image products. Images are produced from the best available original document. 


\section{LEGAL NOTICE}

This report was prepared as an account of Government sponsored work. Neither the United States, nor the Commission, nor any person acting on behalf of the Commission:

A. Makes any warranty or representation, expressed or implied, with respect to the accuracy, completeness, or usefulness of the information contained in this report, or that the use of any information, apparatus, method, or process disclosed in this report may not infringe privately owned rights; or

B. Assumes any liabilities with respect to the use of, or for damages resulting from the use of any information, apparatus, method, or process disclosed in this report.

As used in the above, "person acting on behalf of the Commission" includes any employee or contractor of the Commission, or employee of such contractor, to the extent that such employee or contractor of the Commission, or employee of such contractor prepares, disseminates, or provides access to, any information pursuant to his employment or contract with the Commission, or his employment with such contractor.

Printed in USA. Price $\$ 1.00$. Available from the Clearinghouse for Federal Scientific and Technical Information, National Bureau of Standards,

U. S. Department of Commerce, Springfield, Virginia. 


\section{LEGAL NOTICE}

A Government sponsored work. Neither the United The report was prepared as an account of Government sof the Commission: States, nor the Commission, nor any person acting on beh or implied, with respect to the accuA. Makes any ranty or representation, expressed or jmps in this report, or that the use

A. Mrese or usefulness of the information contalned in this report may not infringe

of any information, apparatus, method, or process disclosed in this report may not in tringe privately owned rights; or

B. Assumes any labilities with respect to the use of, or for damages reert.

se of any information, apparatus, method, or process of the Commission" includes any em-

As used in the above, "person acting or bevoyee of such contractor, to the extent that

ployee or contractor of the Commission, or empor employee of such contractor prepares,

ploye employee or contractor of the Commission, or on contract

disseminates, or provides access to, any informath purser.

ANL- 6417

Metals, Ceramics, and Materials

(TID-4500, 47th Ed.)

AEC Research and

Development Report

ARGONNE NATIONAL LABORATORY

9700 South Cass Avenue

Argonne, Illinois 60439

RELEASED FOR ANNOUNCENENT

IN NUCLEAR SCIENCE ABSTRACTS

THE FABRICATION AND TESTING

OF DEPLETED URANIUM BLANKET SLUGS

FOR EBR-II

by

W. R. Burt, Jr., R. D. McGowan, and C. H. Bean

\section{Metallurgy Division \\ Program 7.10.6}

A portion of the material contained in this report has been reported in the following Metallurgy Division Reports:

$\begin{array}{ll}\text { ANL-5975 (18) } & 1958 \\ \text { ANL-6099 (20-25) } & 1959 \\ \text { ANL-6330(41-47) } & 1960 \\ \text { ANL-6516(42-43) } & 1961\end{array}$

November 1965

Operated by The University of Chicago under

Contract W-31-109-eng-38

with the

U. S. Atomic Energy Commission 
TABLE OF CONTENTS

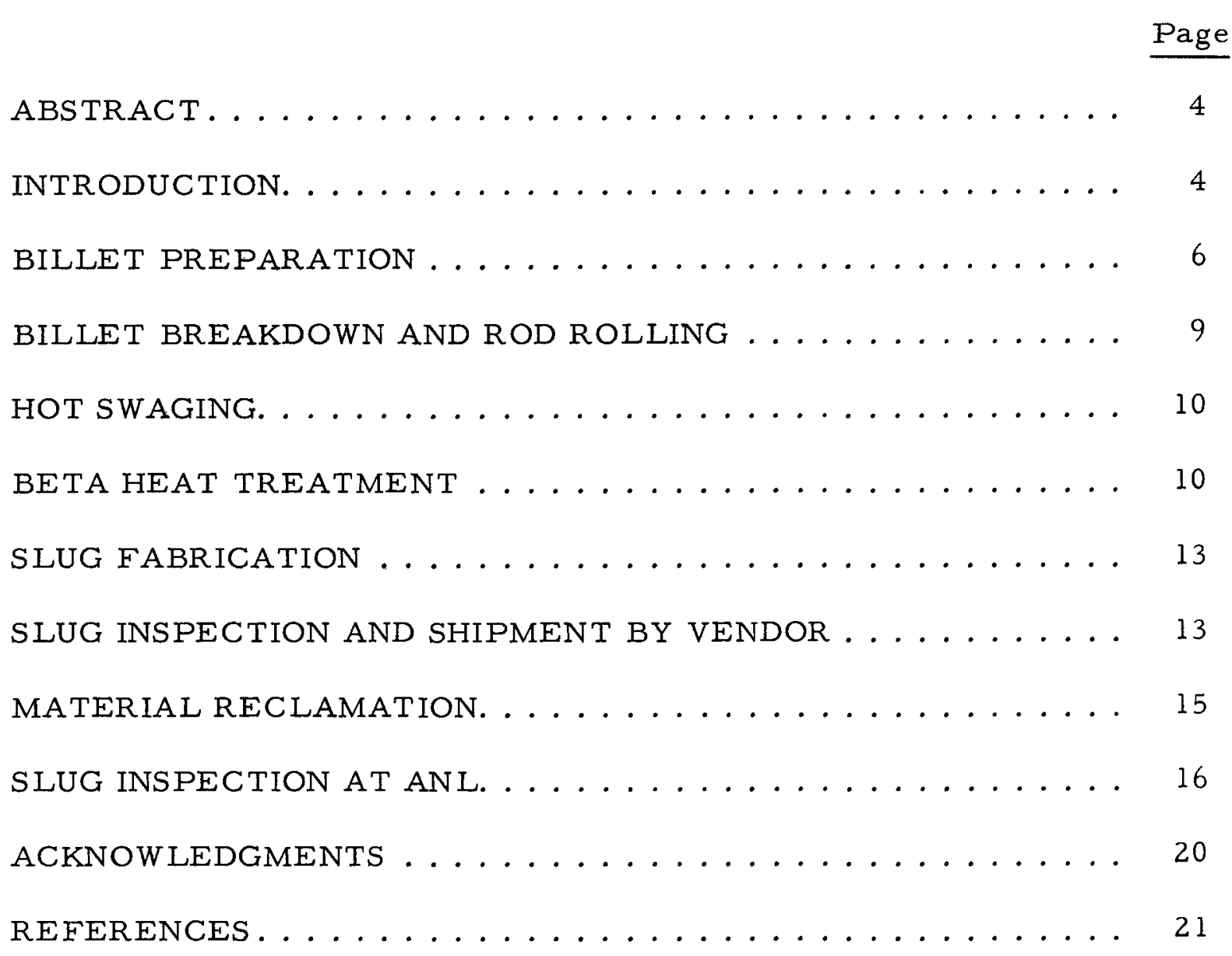




\section{LIST OF FIGURES}

No.

Title

$\underline{\text { Page }}$

1. Overall Flowsheet for Fabrication of Depleted Blanket Slugs . .

2. Photographs of Ultrasonic, Through-transmission Trace and Defective Area in Slug Fabricated by Hot Swaging ........ Il

3. Photomicrograph Showing Typical Inclusion Content of

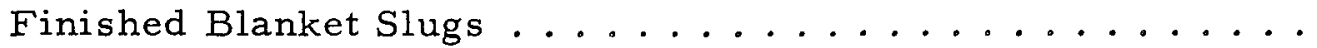

4. Typical Microstructures from Three Different Finished Slugs . 14

5. Overall View of the Ultrasonic, Through-transmission, Test Equipment Used for Inspection of Blanket Slugs . . . . . . . .

6. Photograph of Ultrasonic, Through-transmission Trace and Photomicrographs of Corresponding Areas in EBR-II Smalldiameter Production Blanket Slug .............

7. Ultrasonic, Through-transmission Trace of Small-diameter Slug, Rejected for Abnormally Large Grain Size . . . . . . . .

\section{LIST OF TABLES}

No.

I. Ingot Analyses and Specification Composition ......... 8

II. Density, Volumetric, and Weight Measurements on

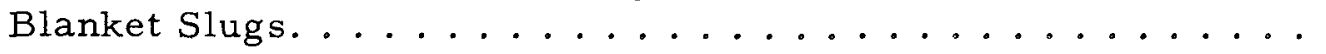




\title{
THE FABRICATION AND TESTING \\ OF DEPLETED URANIUM BLANKET SLUGS \\ FOR EBR-II
}

by

W. R. Burt, Jr., R. D. McGowan, and C. H. Bean

\begin{abstract}
This report covers the production of depleted, unalloyed-uranium blanket slugs used in fabricating blanket elements for the Experimental Breeder Reactor II. Slug production included conversion of $\mathrm{UF}_{4}$ to uranium metal, ingot casting, billet breakdown and rod rolling, beta heat treatment, machining, and inspection.

Emphasis is placed on evaluation of the beta heat treatment via thermal cycling tests and on grain-size uniformity of machined slugs via ultrasonic, through-transmission testing.
\end{abstract}

\section{INTRODUCTION}

The Experimental Breeder Reactor II (EBR-II) at the National Reactor Testing Station in Idaho, is an unmoderated, heterogeneous, sodiumcooled, fast reactor and power plant. The plant includes an integral fuelreprocessing facility where irradiated fuel is processed, fabricated, and assembled for return to the reactor. ${ }^{1}$ The EBR-II is primarily an engineering facility for determining the feasibility of this type of reactor for central-station power-plant applications. More detailed information on the reactor design and experimental purpose can be found in existing publications. ${ }^{2}$

The reactor is divided into three main zones: core, inner blanket, and outer blanket. Each zone consists of a number of right hexagonal elements (subassemblies), $5.82 \mathrm{~cm}$ (2.29 in.) across flats of the hexagon. The annular blanket surrounding the core is separated into two zones: the inner blanket and the outer blanket. The elements for these two zones are identical except for the lower, hexagonal, can adapters. Each element contains 19 blanket rods, each rod containing five $0.2 \%$ depleted, unalloyed-uranium slugs, $1.10 \mathrm{~cm}$ (0.433 in.) in diameter and $27.95 \mathrm{~cm}$ (11 in.) long, which form 
a 127-cm (55-in.) "active" blanket height. These uranium slugs are contained in a Type 304 stainless-steel jacket, with sodium filling the annulus between the slug and the jacket.

The core element contains three sections: upper blanket, core, and lower blarket. The upper and lower blanket sections are identical, each consisting of 19 blanket rods in a hexagonal can. The blanket rod contains two $0.2 \%$ depleted, unalloyed-uranium slugs, $0.80 \mathrm{~cm}(0.316 \mathrm{in.}$ ) in diameter and $22.85 \mathrm{~cm}$ (9 in.) long, which form a $45.7-\mathrm{cm}$ (18-in.) blanket height. As with the inner and outer blanket rods, the slugs fit loosely into a Type 304 stainless-steel jacket, the annular gap being filled with sodium. The number of elements, blanket rods, and depleted uranium slugs necessary for a reactor loading is as follows:

\begin{tabular}{|c|c|c|c|c|}
\hline \multirow[b]{2}{*}{ Location } & \multirow[b]{2}{*}{$\begin{array}{l}\text { Number of } \\
\text { Elements }\end{array}$} & \multirow[b]{2}{*}{$\begin{array}{c}\text { Number of } \\
\text { Blanket Rods } \\
\text { (19 per element) }\end{array}$} & \multicolumn{2}{|c|}{ Number of Uranium Slugs } \\
\hline & & & $\begin{array}{c}\text { Small } \\
\text { Diameter } \\
(2 \text { per rod })\end{array}$ & $\begin{array}{c}\text { Large } \\
\text { Diameter } \\
\text { (5 per rod) }\end{array}$ \\
\hline Upper blanket & 47 & 893 & 1,986 & - \\
\hline Lower blanket & 47 & 893 & 1,986 & - \\
\hline Inner blanket & 66 & 1,254 & - & 6,270 \\
\hline Outer blanket & 510 & 9,690 & - & 48,450 \\
\hline TOTAL & 670 & 12,730 & 3,972 & 54,720 \\
\hline
\end{tabular}

A total of 14,000 upper and lower blanket slugs and 82,000 inner and outer blanket slugs were required. The additional slugs compensated for losses in inspection and rod assembly and, more importantly, provided additional rods for replacing the upper and lower blanket sections in fuel-element recycling and for demonstrating plutonium recovery from breeding in the blanket elements.

This report covers the production of depleted-uranium ingots by the Union Carbide Corp. at Paducah, Kentucky; fabrication of the blanket slugs by the National Lead Co. at Fernald, Ohio; and inspection of the blanket slugs at Argonne National Laboratory, Argonne, Illinois. The assembly and inspection of the blanket rods are covered in a separate report. ${ }^{3}$ The overall flowsheet for fabrication of the depleted-uranium blanket slugs is shown in Fig. 1.

Unalloyed uranium was selected for the blanket material to simplify the reprocessing cycle for blanket material. All rolled uranium rod stock received a beta heat treatment and water quench to minimize the effects of thermal cycling and irradiation during reactor operations. 


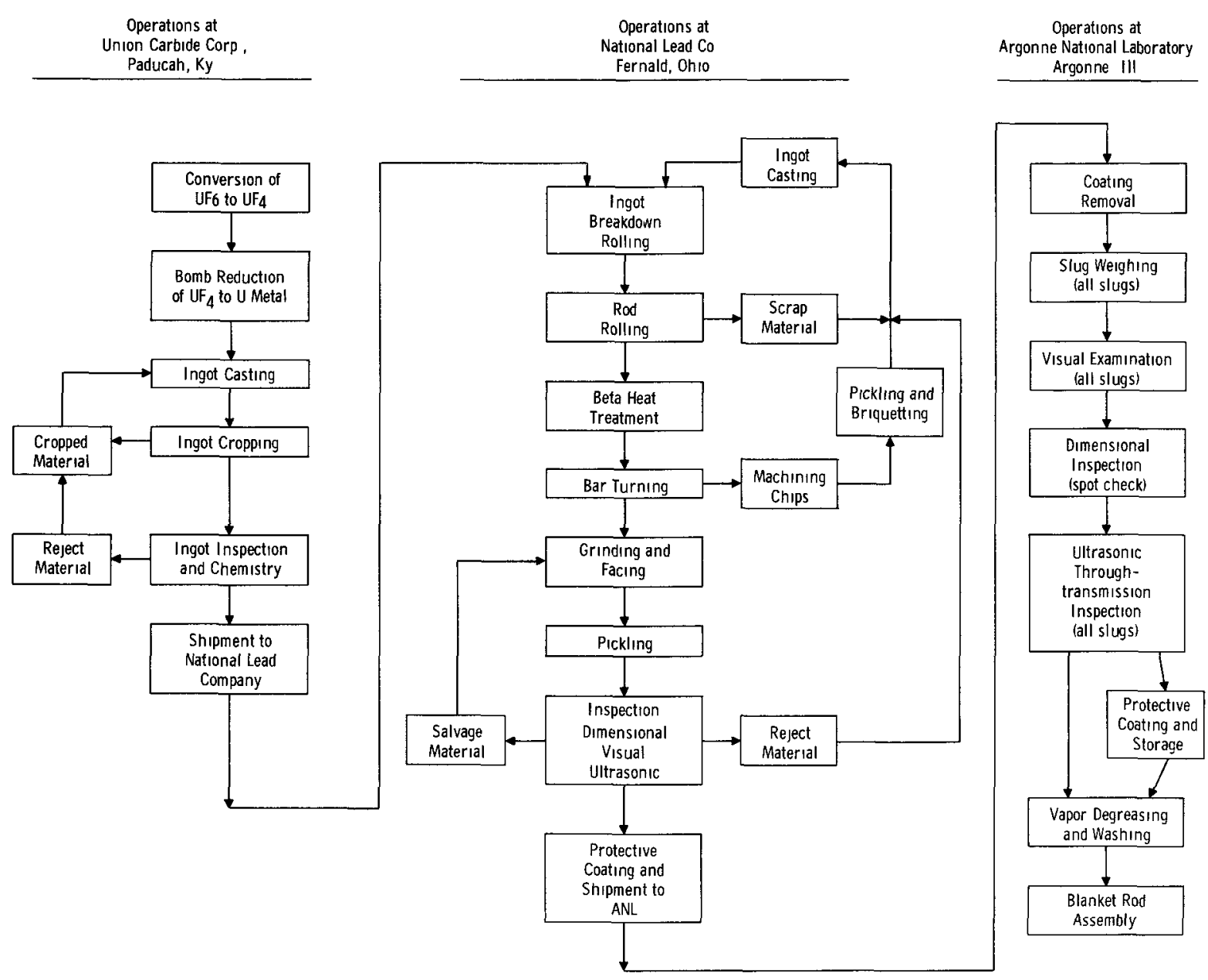

Fig. 1. Overall Flowsheet for Fabrication of Depleted Blanket Slugs

\section{BILLET PREPARATION}

Production of the depleted-uranium castings for subsequent hot rolling and blanket-slug fabrication was carried out by the Union Carbide Corp. at Paducah, Kentucky. The work included conversion of $\mathrm{UF}_{6}$ to $\mathrm{UF}_{4}$, reduction of $\mathrm{UF}_{4}$ to uranium metal, and casting of 19-cm (7.5-in.)-diam, $455-\mathrm{kg}$ (1000-lb) ingots with a minimum length of $61 \mathrm{~cm}(24 \mathrm{in.}$.

After conversion of gaseous $\mathrm{UF}_{6}$ of the desired isotopic composition to the uranium tetrafluoride salt, the $\mathrm{UF}_{4}$ was reduced to uranium metal by a magnesium-reduction operation. The thermodynamics and details of the reduction process are described in detail elsewhere. ${ }^{4}$ Briefly, the uranium fluoride salt and magnesium powder, in an amount slightly in excess of the stoichiometric requirements, were placed in a magnesium fluoride-lined steel bomb. The bomb was placed in a heating furnace to preheat the contents to the reduction ignition temperature. After the reaction took place, the bomb was removed from the furnace and allowed to cool until the 
uranium metal and slag had separated and solidified. The reaction vessel was then opened, and the uranium metal in the form of a $455-\mathrm{kg}(1000-\mathrm{lb})$ derby was removed. The derby was heated in air for $2 \mathrm{hr}$ at $600^{\circ} \mathrm{C}$ and water-quenched to remove adherent slag and other foreign material. This technique replaces the older method of acid pickling and abrasive blast cleaning.

The uranium derbies were converted into ingots by melting and casting in steel-shell induction-heated vacuum furnaces equipped for bottom pouring. Two furnaces were utilized, each having a capacity of approximately $685 \mathrm{~kg}$ (1500 1b) of uranium, which could be heated to a maximum of $1550^{\circ} \mathrm{C}$. Mechanical pumping systems maintained vacuums of approximately 1 to 2 Torr during the melting and casting cycle. Melting and casting were done in graphite crucibles and molds coated with mullite $\left(3 \mathrm{Al}_{2} \mathrm{O}_{3} \cdot 2 \mathrm{SiO}_{2}\right)$. The coatings were applied by brushing a water slurry on the surface and drying at temperatures of $200-300^{\circ} \mathrm{C}$. The graphite molds were preheated prior to casting by electrical-resistance-type strip heaters in one furnace, and by preheating prior to insertion in the second furnace. Molds were preheated to approximately 525 to $550^{\circ} \mathrm{C}$.

A typical power-time cycle used in producing the $19-\mathrm{cm}(7.5-\mathrm{in}$. diam, 455-kg (1000-1b)-castings was as follows:

\begin{tabular}{cc}
$\begin{array}{c}\text { Furnace Output } \\
(\mathrm{kW})\end{array}$ & Time (min) \\
\hline $25-40$ & 5 \\
50 & 5 \\
75 & 5 \\
100 & 5 \\
175 & 135 (maximum)* \\
Power off & $5--$ pour \\
*Maximum time or 1400-1425 $\mathrm{C}$ (optical \\
reading), whichever occurs first.
\end{tabular}

After the castings were removed from the furnace, they were waterquenched to facilitate cooling and transferred to a cut-off station for cropping of the hot top and pipe. From 90 to $135 \mathrm{~kg}$ (200 to $300 \mathrm{lb})$ of hot top was removed as was all visible pipe extending down into the casting. All cropping was done with power hacksaws. The cropped castings were inspected for visual surface defects. Ingots were rejected for pipe greater than $0.32 \mathrm{~cm}(1 / 8 \mathrm{in}$ ) in diameter and $0.64 \mathrm{~cm}(1 / 4 \mathrm{in.})$ in depth, pinhole porosity or surface imperfections covering an area greater than $39 \mathrm{sq} \mathrm{cm}$ ( $6 \mathrm{sq}$ in.), or depressions such as cold shuts deeper than $0.32 \mathrm{~cm}(1 / 8 \mathrm{in}$.). Fins resulting from using split graphite molds were ground off. Cropped material and defective ingots were recycled through the melting and casting process. 
A total of 225 acceptable castings were produced by utilizing $106,726 \mathrm{~kg}(234,798 \mathrm{lb})$ of derby charge material and $16,775 \mathrm{~kg}(36,905 \mathrm{lb})$ of recycle material, which produced $105,704 \mathrm{~kg}(232,549 \mathrm{lb})$ of acceptable billet material. This represented a yield of $80.6 \%$ on total charge material and $99.0 \%$ on original derby material.

Specifications on ingot chemistry are shown in Table I, together with average, maximum, and minimum contents for all ingots produced. During the initial production of these castings, it was found that the carbon content of the ingots was below the desired lower limit of $200 \mathrm{ppm}$. Therefore, a total of approximately $200 \mathrm{~g}$ of -20 mesh carbon powder was added to the charge to insure an ingot carbon content within the specified limits. A 200 - to 500-ppm level of carbon was desired to improve the hotrolling characteristics of the metal and to promote grain-size uniformity.

TABLE I. Ingot Analyses and Specification Composition

\begin{tabular}{|c|c|c|c|c|}
\hline \multirow{2}{*}{ Element } & \multirow{2}{*}{ Specification } & \multicolumn{3}{|c|}{ Ingot Analyses, ppm* } \\
\hline & & High & Low & Average \\
\hline $\mathrm{U}^{235}$ & $0.22 \pm 0.02 \mathrm{w} / \mathrm{o}$ & 0.2313 & 0.2087 & 0.2148 \\
\hline Boron & 1 ppm max & 1 & NF & NMA \\
\hline Cadmium & 1 ppm max & $<1$ & NF & NMA \\
\hline Carbon & $\begin{array}{c}750 \text { ppm max, } \\
\text { preferably } 200-500 \text { ppm }\end{array}$ & 740 & 60 & 308 \\
\hline Chromium & $100 \mathrm{ppm} \max$ & $<20$ & $\mathrm{NF}$ & NMA \\
\hline Copper & $100 \mathrm{ppm} \max$ & 70 & 4 & 15 \\
\hline Iron + Nickel & $300 \mathrm{ppm} \max$ & 290 & 70 & 160 \\
\hline Magnesium & 25 ppm $\max$ & 10 & $<5$ & NMA \\
\hline Manganese & $150 \mathrm{ppm} \max$ & 140 & $<2$ & 48 \\
\hline Nitrogen & $100 \mathrm{ppm} \max$ & 88 & $<10$ & 24 \\
\hline Silicon & $150 \mathrm{ppm} \max$ & $160 * *$ & 15 & 75 \\
\hline All others ${ }^{t}$ & $400 \mathrm{ppm} \max$ & 280 & 7 & 82 \\
\hline
\end{tabular}

* Based on 225 ingots.

**One ingot analyzed 160 ppm. All others below 150 ppm.

'Includes $\mathrm{Al}, \mathrm{Be}, \mathrm{Co}, \mathrm{P}, \mathrm{Pb}, \mathrm{Sn}, \mathrm{V}$, and $\mathrm{Zn}$.

NF--Not found.

NMA--No meaningful average since analyses were usually given as "less than..." 


\section{BILLET BREAKDOWN AND ROD ROLLING}

The 19-cm (7.5-in.)-diam, 455-kg (1000-1b) uranium billets were fabricated into finished blanket slugs by the National Lead Co. at Fernald, Ohio.

For breakdown rolling, the billets were preheated for 60 to $80 \mathrm{~min}$ in a carbonate salt bath $\left(75 \% \mathrm{~K}_{2} \mathrm{CO}_{3}-25 \% \quad \mathrm{Li}_{2} \mathrm{CO}_{3}\right)$ at 625 to $650^{\circ} \mathrm{C}$ and broken down on a 56-cm (22-in.), two-high, Birdsboroblooming mill. A roll schedule of 19 passes was employed, and the billets finished as $3.8 \times 6.4-\mathrm{cm}$ (1.5 $\times 2.5$-in.) oval bars. Each oval bar was hot-sheared into two $5.2-\mathrm{m}$ (17-ft) lengths.

The oval bars were transferred to an equalizing salt-bath furnace (composition similar to the carbonate salt bath mentioned earlier) for a minimum soak of $12 \mathrm{~min}$ at $650^{\circ} \mathrm{C}$ prior to further reduction on a continuousbar mill. The mill consisted of six Birdsboro stands in tandem. Mills 1, 3, and 5 were vertical mills with oval-edge-oval rolls; mills 2,4 , and 6 had horizontal round rolls. The oval bars were reduced to $3.8-\mathrm{cm}(1.5-\mathrm{in})-$. diam rounds, with nominal reductions of $15 \%$ per stand after an initial $6 \%$ reduction in the first mill. Bars entered the first mill at $27 \mathrm{~m} / \mathrm{min}(90 \mathrm{ft} / \mathrm{min})$ and left the No. $6 \mathrm{mill}$ at $76 \mathrm{~m} / \mathrm{min}(250 \mathrm{ft} / \mathrm{min})$, the exit-bar temperature being approximately 590 to $620^{\circ} \mathrm{C}$. The $12-\mathrm{m}(40-\mathrm{ft})$-long bars leaving the No. 6 mill were fed into a Birdsboro flying shear, where they were cut into $6-\mathrm{m}(20-\mathrm{ft})$ lengths and $r$ un onto a cooling bed.

Further rolling of the bars, first to a $2.21-\mathrm{cm}(0.875-$ in.) diam and then to a $1.27-\mathrm{cm}(0.500-$ in.) diam, was performed in two additional passes through the continuous mill at the same preheat temperatures and rolling speeds as in the initial pass. Reductions of $17 \%$ per pass were used in these last two schedules. The finished rods were cut into approximately $6-\mathrm{m}(20-\mathrm{ft})$ lengths. Surface quality of the $1.27-\mathrm{cm}(0.500-\mathrm{in}$.$) -diam bars$ was excellent. Some ovality was evident, but the bars finished within the limits of $1.27 \pm 0.02 \mathrm{~cm}(0.500 \pm 0.007 \mathrm{in.})$ set on the rolled diameter.

An initial shipment of $82,373 \mathrm{~kg}(181,221 \mathrm{lb})$ of ingots was rolled to $1.27-\mathrm{cm}$ (0.500-in.)-diam rod. (NOTE: This represents the initial shipment of material from Paducah on which yields were measured.) From this material, approximately $27,000 \mathrm{~m}(90,000 \mathrm{ft})$ of $1.27-\mathrm{cm}(0.500-\mathrm{in}$.)-diam bar stock weighing $71,686 \mathrm{~kg}(157,710 \mathrm{lb})$ were produced, representing an $87.0 \%$ yield. A total of $9,745 \mathrm{~kg}(21,464 \mathrm{lb})$ of solid scrap, representing $11.8 \%$ of the material, was produced and later recycled. The remaining $1.2 \%$ consisted of fines and oxide scale lost during the rolling operation. The $87 \%$ yield of acceptable $1.27-\mathrm{cm}$ (0.500-in.)-diam bar stock was somewhat less 
than expected and was due to problems of "cobbling"* and dimensional control in the initial attempts to roll $2.21-\mathrm{cm}(0.875-\mathrm{in}$.)-diam rods to a $1.27-\mathrm{cm}(0.500-$ in. $)$ diameter.

\section{HOT SWAGING}

Since many small-diameter [0.802-cm (0.316-in.)] blanket slugs were required, attempts were made to hot-swage $1.27-\mathrm{cm}(0.500-$ in.)-diam bar stock to a smaller diameter to reduce losses on machining to the final size. Rod stock was preheated in a carbonate salt bath to 615 to $650^{\circ} \mathrm{C}$ and hot-swaged on a Fenn $6 \mathrm{~F}$ machine with the aid of a power-driven feed mechanism. Feed rates were approximately 51 to $64 \mathrm{~cm} / \mathrm{min}(20$ to $25 \mathrm{in} . / \mathrm{min})$. Overall reductions of 40 to $60 \%$ were taken. While hot swaging proved feasible, adherence of the salt from the preheat bath presented difficulties in maintaining uniform rod feed and in obtaining a uniform surface finish on the as-swaged rod. A series of as-swaged rods was given a $725^{\circ} \mathrm{C}$ beta heat treatment in a chloride salt bath, followed by a water quench. Metallographic examination of both as-swaged and heat-treated material revealed an excessive variation in grain size. A significant number of swaged rods also exhibited centerline cracks resulting from the heavy swaging operation. Figure 2 shows (1) a typical crack indication on the ultrasonic throughtransmission trace produced in nondestructive testing of a swaged rod, and (2) a photomicrograph of the actual defect.

Accordingly, hot swaging was abandoned in favor of machining the small-diameter slugs from $1.27-\mathrm{cm}$ (0.500-in.)-diam bar.

\section{BETA HEAT TREATMENT}

The anisotropic characteristics of alpha-rolled uranium and subsequent dimensional instability upon irradiation or thermal cycling has been well studied and reported elsewhere. ${ }^{5,6}$ Specifications for the EBR-II blanket slugs required a beta heat treatment and water quench to minimize preferred orientation and subsequent deleterious performance during reactor operation. Based on tests run at National Lead, the proposed production beta heat treatment for the rolled bar stock consisted of heating in a sodium chloridepotassium chloride salt bath to $735^{\circ} \mathrm{C}$ and holding at temperature for $5 \mathrm{~min}$. The bars would then be transferred in air to a $55^{\circ} \mathrm{C}$ water quench, the transfer time being approximately $18 \mathrm{sec}$. To further evaluate the proposed heat treatment, production-rolled material was heat-treated at Argonne National Laboratory and evaluated by thermal cycle testing. The heat treatments consisted on heating for $5 \mathrm{~min}$ at $730^{\circ} \mathrm{C}$, followed by three different cooling rates.

* Cobbling" means: The failure of the bar to pass through the set of rolls in a continuous mill, with subsequent buckling and accumulation of material (between roll stands) leaving the previous stand. 


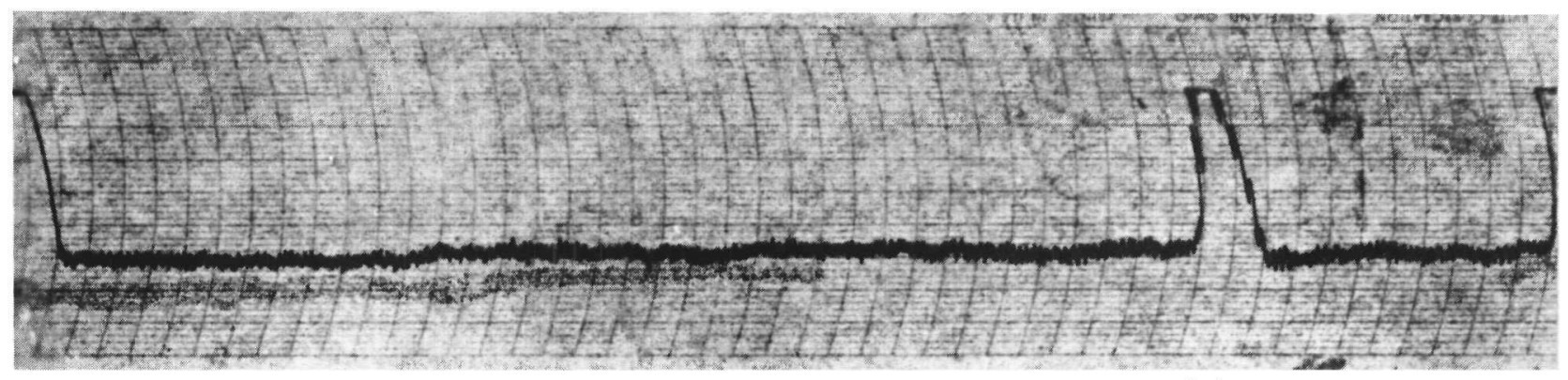
$\uparrow_{\text {End of Slug }}$ 106-5191

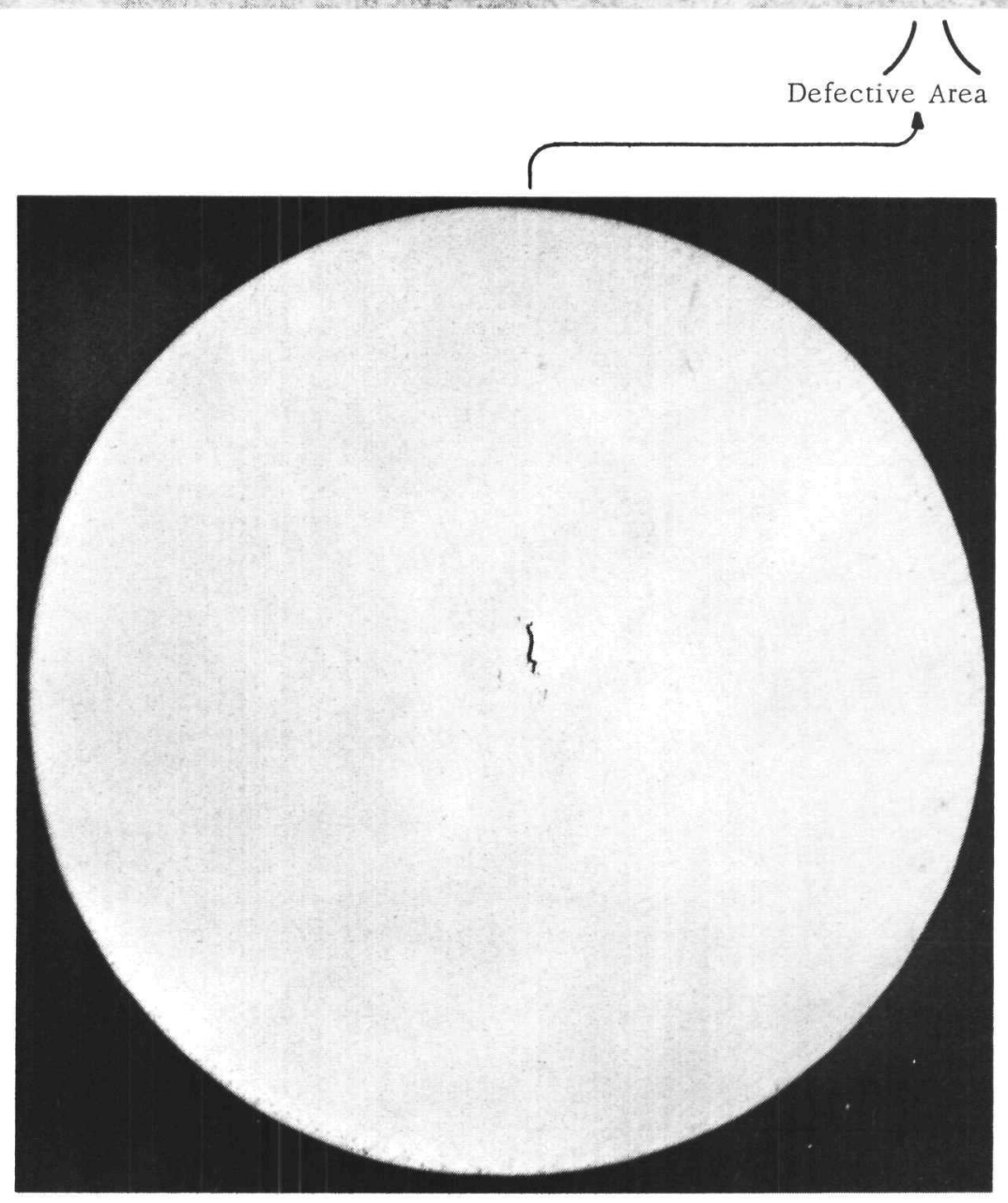

26081--ANL - $106-5190$

Fig. 2. Photographs of Ultrasonic, Through-transmission Trace and Defective Area in Slug Fabricated by Hot Swaging 
Samples were cooled by quenching in $55^{\circ} \mathrm{C}$ water after an 18 -sec transfer time to simulate the production treatment, air-cooled from the beta-heattreatment temperature, or transferred in 5 to $8 \mathrm{sec}$ to a $25^{\circ} \mathrm{C}$ water quench to effect a more drastic quenching condition. The samples were thermally cycled between 300 and $600^{\circ} \mathrm{C}$, these temperatures being the calculated values normal to the operating conditions of the reactor blanket. The thermal cycle consisted of $2 \mathrm{hr}$ at $300^{\circ} \mathrm{C}$, heating to $600^{\circ} \mathrm{C}$ in $30 \mathrm{~min}$, holding at $600^{\circ} \mathrm{C}$ for $1 \mathrm{hr}$, and cooling to $300^{\circ} \mathrm{C}$ in $30 \mathrm{~min}$. At preselected intervals of 50,150 , 300 , and 500 thermal cycles, the samples were withdrawn from the cycling facility and dimensionally inspected.

After thermal cycling, all sample surfaces were generally rough but there was no indication of warping, necking, cracking, or flaking. After 50 cycles, all samples underwent a negative rate of elongation; the material receiving the more drastic water quench showed the greatest negative rate, and the air-cooled material showed the least negative rate. From 50 to 150 cycles, all material showed a positive rate of elongation. After approximately 150 cycles, the growth rate remained essentially constant, regardless of quench history. The growth rate of all samples tended to converge to a value less than $10^{-6} \mathrm{~mm} / \mathrm{mm} /$ cycle $(10 \mu \mathrm{in}$./in./cycle). No significant difference based on the various cooling rates was observed. On this basis, the proposed production treatment was deemed acceptable.

An initial group of finished $1.10-\mathrm{cm}$ (0.433-in.)-diam slugs was processed through the heat treatment and machining operations and shipped to ANL for evaluation. Six different rods were sectioned in a longitudinal direction (parallel to the rolling direction of the rod stock), and one rod was sectioned in two separate locations. All rods exhibited minor discontinuous inclusions aligned in the rolling direction, as shown in Fig. 3.

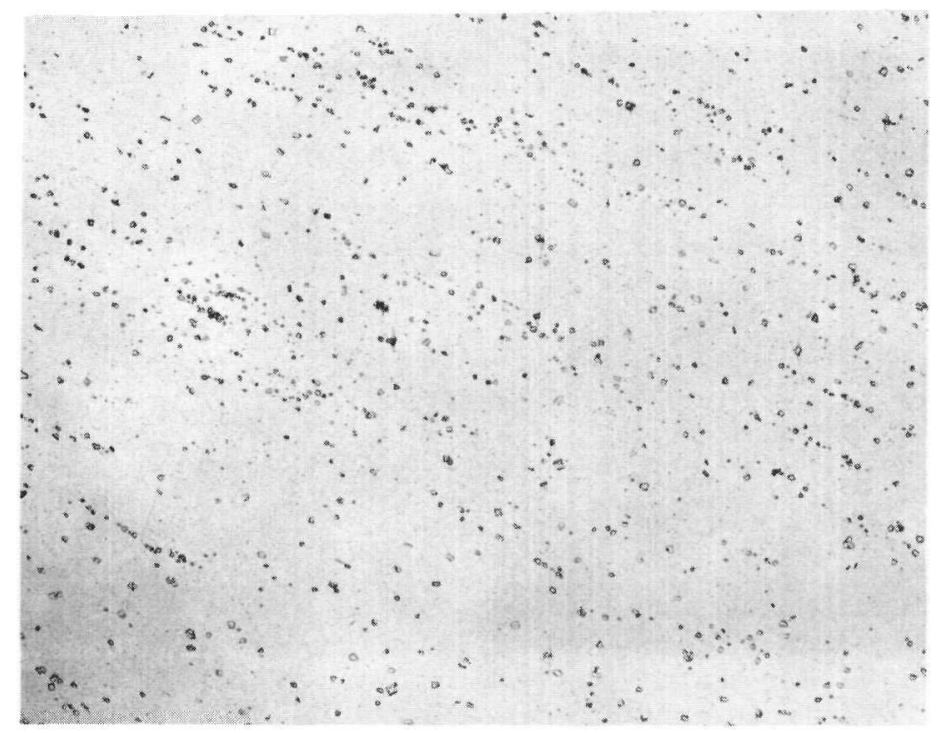

Fig. 3

Photomicrograph Showing Typical Inclusion Content of Finished Blanket Slugs 
The grain size appeared uniform in all samples and in the two samples from the same rod. On a line-intercept method, the average grain diameter was approximately $0.10 \mathrm{~mm}$, which was within the specification size of 0.05 to $0.15 \mathrm{~mm}$. Figure 4 shows the typical microstructure from three different finished slugs.

In addition to evaluating the proposed beta-heat-treatment process, a study was made to determine the stability of the beta-heat-treatment structure with the subsequent sodium-bonding heat treatment given the assembled blanket rod at ANL. To insure bonding, loaded blanket rods normally received a heat treatment of $16 \mathrm{hr}$ at $450^{\circ} \mathrm{C}$. Before actual determination of the production bonding cycle, it was thought that a cycle of $24 \mathrm{hr}$ at $550^{\circ} \mathrm{C}$ might be necessary. Accordingly, beta-heat-treated production material was vacuum-annealed for $24 \mathrm{hr}$ at the higher temperature of 550 to $560^{\circ} \mathrm{C}$ for evaluation of possible microstructural changes. Metallographic examination revealed that the material had undergone recrystallization, apparently due to stresses resulting from the water quench after the beta heat treatment. However, neither hardness nor grain-size measurements indicated any deleterious effects as a result of the heat treatment.

\section{SLUG FABRICATION}

Following a straightening operation performed on a Medart rod straightener, the beta-treated bars were bar-turned to approximately $1.15-\mathrm{cm}(0,45-\mathrm{in}$,$) diameter for material for the large-diameter slugs and$ to approximately $0.84 \mathrm{~cm}$ ( $0.330 \mathrm{in.})$ for material for the small-diameter slugs. Two passes through the bar-turning machine were required to produce stock for the small-diameter slugs. Following turning, the bars were rough-cut to length on an abrasive wheel, leaving approximately $0.08 \mathrm{~cm}$ $(0.031$ in.) over the finished slug length. The rough-cut slugs were centerless-ground to their final diameters in two or three heavy passes, with a final light pass for a good surface finish. While specifications called for a 2.5-micron (100- $\mu$ in.) finish, actual finishes were approximately 1.6 microns $(64 \mu \mathrm{in}$.$) . The good surface finish was required to promote so-$ dium wetting and to facilitate visual inspection for surface defects. The final diameters were held to within $\pm 0.0012 \mathrm{~cm}( \pm 0.0005 \mathrm{in}$.). Slug ends were faced to within $\pm 0.012 \mathrm{~cm}( \pm 0.005 \mathrm{in}$.$) of the nominal final length, and$ the ends were deburred. The machined slugs were degreased, given a light pickle in cold $\mathrm{HNO}_{3}$ and a hot-water rinse, and dried in hot air. The purpose of the nitric acid pickle was to facilitate detection of surface defects in subsequent visual examination.

\section{SLUG INSPECTION AND SHIPMENT BY VENDOR}

Following the pickling cycle, all slugs were given a visual surface inspection for pits, seams, laps, voids, or inclusions greater than $0.08 \mathrm{~cm}$ $(0.031$ in. $)$ in any direction. After a dimensional inspection of length and 

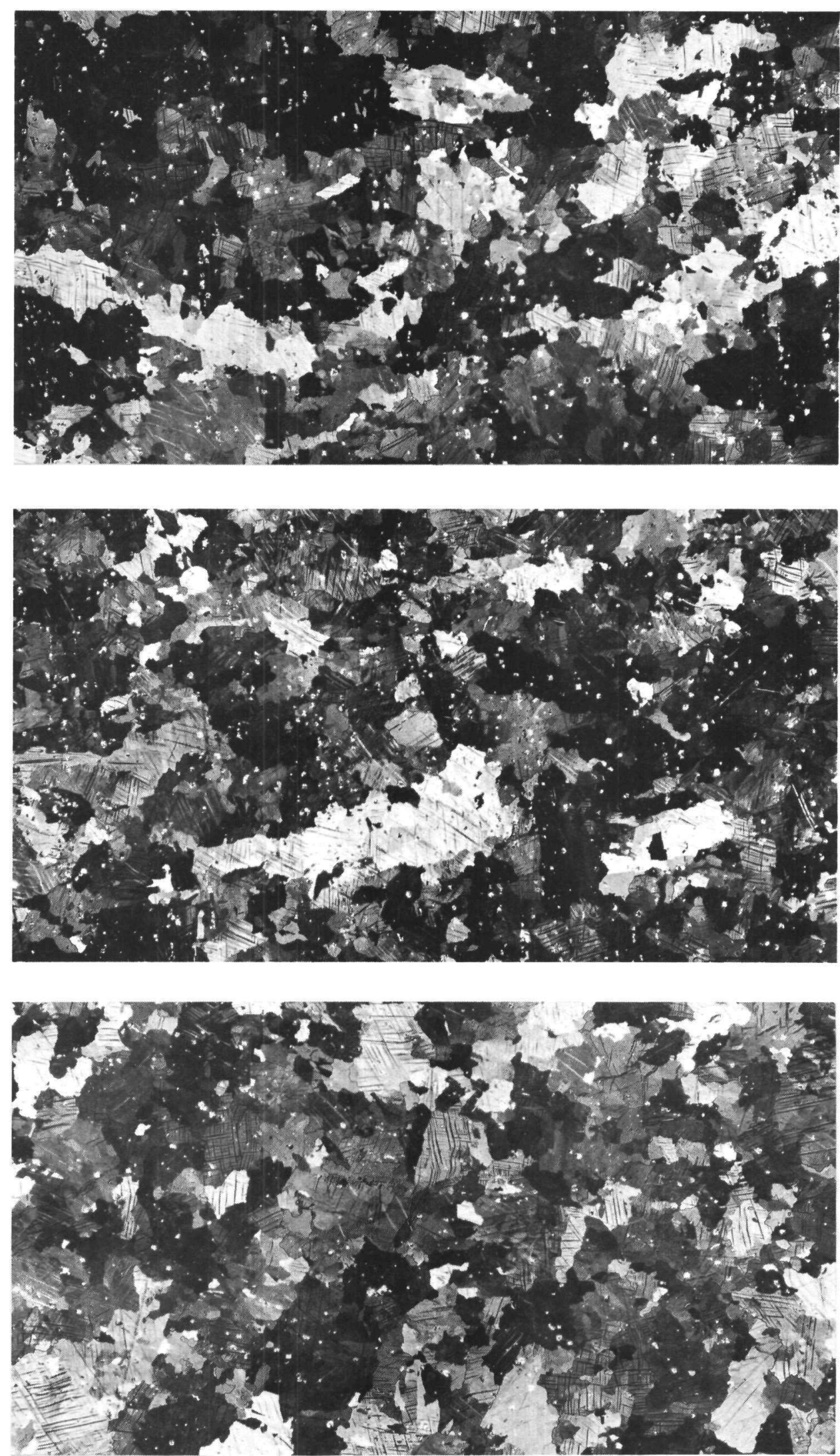

Fig. 4. Typical Microstructures from Three Different Finished Slugs 
diameter and an inspection for straightness, the slugs were given an ultrasonic velocity test for detection of untransformed alpha phase present in material that had not received the proper beta heat treatment. The ultrasonic test was made with the probes immersed in a tank of Shell Oil Company No. 210 Ensis oil, a paraffin-base derivative. The oil provided an adequate transmission medium for the test and protected the slugs from surface pitting, which occurred if uncoated slugs were left sitting in open air for a day or two. After the test, the slugs were supported vertically to allow the excess oil to drain off and leave a semisolid, adherent, protective coating on the slug.

The coated slugs were packed vertically in wooden boxes lined with aluminum foil for shipment to Argonne National Laboratory.

The following is a tabulation of inspection results at National Lead on small-diameter, upper and lower blanket slugs:

$\begin{array}{lr}\begin{array}{c}\text { Slugs received from machining operations } \\ \text { New stock }\end{array} & 20,530 \\ \text { Recycle stock } & \frac{470}{21,000} \\ \text { Total } & 16,050 \\ \text { Acceptable slugs shipped to ANL } & 4,470 \\ \text { Scrap slugs } & 10 \\ \text { Slugs for laboratory evaluation } & 470 \\ \text { Slugs recycled } & \end{array}$

The acceptable slugs represent a $78.2 \%$ yield from the $20,530 \mathrm{ma}-$ chined slugs. The 16,050 slugs represent approximately $11,350 \mathrm{~kg}(25,000 \mathrm{lb})$ of $1.2-\mathrm{cm}\left(0.500-i n_{\circ}\right)$-diam bar stock. Of the reject material, the dimensional inspection accounted for approximately two-thirds of the rejects; visual rejects (seams, pits, nicks, machining marks, or other surface defects larger than $0.08 \mathrm{~cm}$ in any direction) accounted for the balance.

No detailed records were kept on inspection of large-diameter slugs, but the yield of good slugs was equal to, or slightly better than, that obtained on the small-diameter slugs. Again, dimensional variations accounted for the majority of the rejected slugs. Slugs that were oversize in diameter or length were recycled through the grinding or facing operation to bring the slugs to within specified tolerances.

\section{MATERIAL RECLAMATION}

To increase the material yield of acceptable slugs from the initial ingots, machining chips, rejected slugs from inspection, and other scrap uranium metal were reclaimed. Chips from machining were pickled in acid to remove surface oxide and briquetted into compacts suitable for 
charging to a remelt operation. These briquets, together with blanket slugs and other metal, were charged into graphite crucibles, vacuum-induction melted, and cast into graphite molds in a manner similar to that described for the initial ingots produced by the Union Carbide Corp. All reclamation was done at the facilities of the National Lead Company. An additional 40 ingots were realized through this reclamation process, including eight ingots that were slightly out of specification as to minor elements but were accepted by Argonne National Laboratory.

These ingots resulting from reclamation were processed in a manner similar to that described earlier for the original ingots.

\section{SLUG INSPECTION AT ANL}

Prior to assembly into blanket tubes, all uranium slugs received the following inspections:

(1) Visual examination of the surface for pits, laps, seams, cracks, or other defects greater than $0.08 \mathrm{~cm}(0.031 \mathrm{in}$.$) in any direction.$

(2) Weight checks to assure an acceptable density.

(3) Ultrasonic through-transmission testing for detecting internal defects such as cracks, for assuring proper beta heat treatment, and for determining adequacy and uniformity of the grain size.

(4) A dimensional and straightness recheck on every 24 th slug.

To meet the specification of a minimum density of $18.7 \mathrm{~g} / \mathrm{cc}$ for blanket slugs, a group of 60 slugs was taken from small-diameter slugs and a similar group from large-diameter slugs. The two groups were measured by an immersion technique for density and volume. The resulting data are shown in Table II. The average density was $18.96 \mathrm{~g} / \mathrm{cc}$.

TABLE II. Density, Volumetric, and Weight Measurements on Blanket Slugs

\begin{tabular}{|c|c|c|}
\hline \multirow{2}{*}{ Measurement } & \multicolumn{2}{|c|}{ Blanket Slug Size } \\
\hline & $\begin{array}{c}1.10-\mathrm{cm}(0.433-\mathrm{in} .)-\text { diam } \\
\text { Group of } 60 \text { Slugs }\end{array}$ & $\begin{array}{c}0.80-\mathrm{cm}(0.316-\text { in. }) \text {-diam, } \\
\text { Group of } 60 \text { Slugs }\end{array}$ \\
\hline \multicolumn{3}{|l|}{ Density } \\
\hline Average & $18.96 \mathrm{~g} / \mathrm{cc}$ & $18.96 \mathrm{~g} / \mathrm{cc}$ \\
\hline Range & 18.89 to $19.03 \mathrm{~g} / \mathrm{cc}$ & 18.89 to $19.02 \mathrm{~g} / \mathrm{cc}$ \\
\hline \multicolumn{3}{|l|}{ Volume } \\
\hline Average & $26.542 \mathrm{cc}$ & $11.543 \mathrm{cc}$ \\
\hline Range & 25.484 to $26.604 \mathrm{cc}$ & 11.508 to $11.570 \mathrm{cc}$ \\
\hline Variance $\left(S^{2}\right)$ & 0.000668 & 0.000192 \\
\hline Standard Deviation (S) & 0.0259 & 0.0138 \\
\hline \multicolumn{3}{|l|}{$\underline{\text { Weight }}$} \\
\hline Average & $503.34 \mathrm{~g}$ & $218.89 \mathrm{~g}$ \\
\hline
\end{tabular}


The tolerances on slug diameters being $\pm 0.0013 \mathrm{~cm}( \pm 0.0005 \mathrm{in}$.$) and on$ slug lengths being $\pm 0.013 \mathrm{~cm}$ ( $\pm 0.005 \mathrm{in}$.$) , and the average measured den-$ sity being significantly greater than the minimum specified density, it was possible to calculate a minimum slug weight that would insure that all slugs within specified dimensions were above the required minimum density of $18.7 \mathrm{~g} / \mathrm{cc}$. All finished slugs were weighed; those whose weight fell below the calculated minimum weight received an actual density measurement.

The purpose of the ultrasonic through-transmission test was threefold:

(1) To discover any internal defects, such as cracks, pits, etc., larger than $0.08 \mathrm{~cm}(0.031 \mathrm{in}$.$) in any direction.$

(2) To insure that the structure consisted of beta-treated material.

(3) To indicate areas of relatively large grain size in betatreated material.

A permanent 1:1 trace from a strip-chart recorder was obtained on each slug. The uranium slugs were rotated and fed between the transducer heads at a speed of $61 \mathrm{~cm} / \mathrm{min}(2 \mathrm{ft} / \mathrm{min})$ by skewed rolls. Figure 5 shows the overall ultrasonic test equipment and recorder.

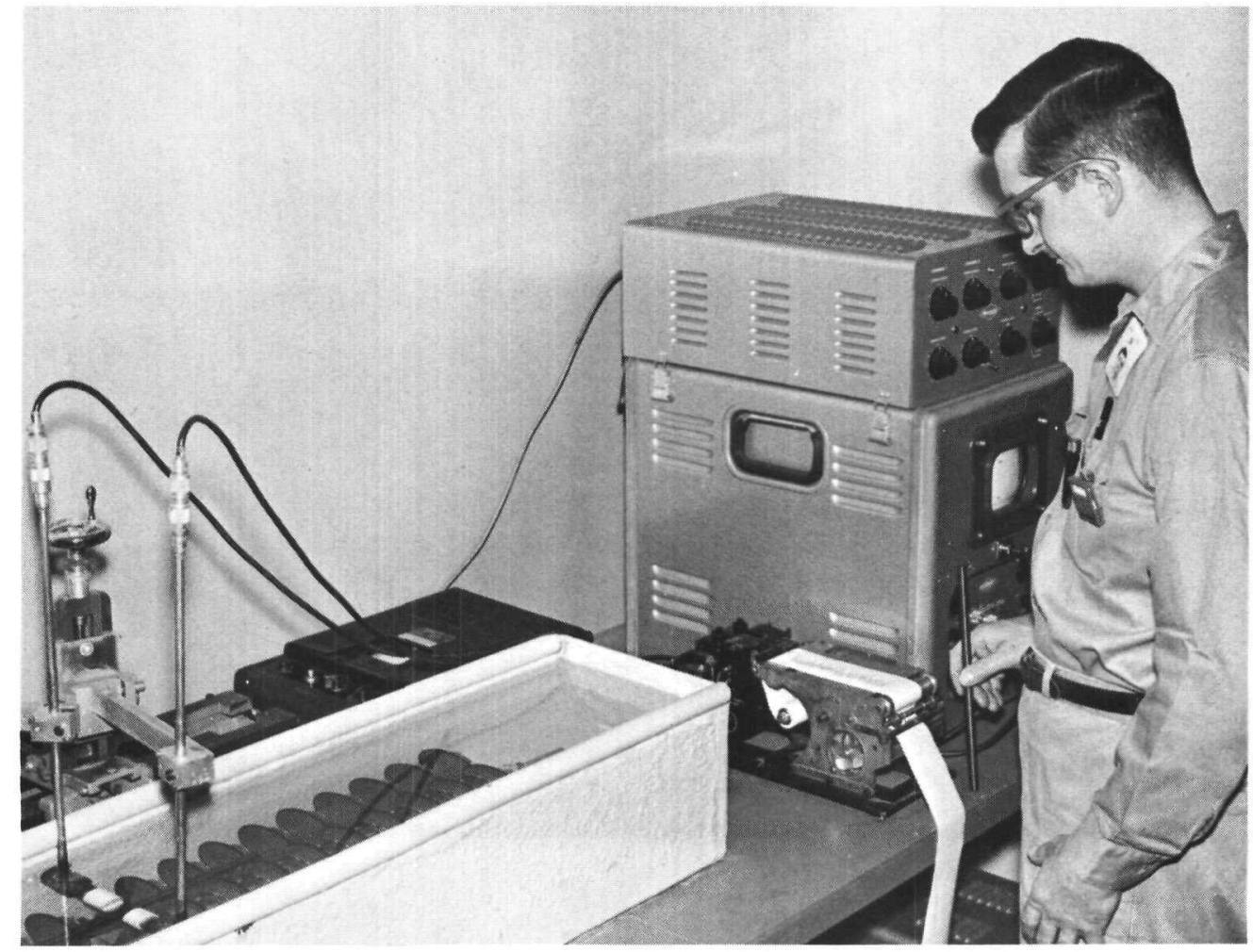

$106-4978$

Fig. 5. Overall View of the Ultrasonic, Through-transmission, Test Equipment Used for Inspection of Blanket Slugs 
The typical microstructure of beta-treated material is shown in Fig. 4., where microstructures from three different rods show a similar grain size. Figure 6 shows the microstructure and ultrasonic trace from a rod rejected because of an abnormally large grain size over three-fourths

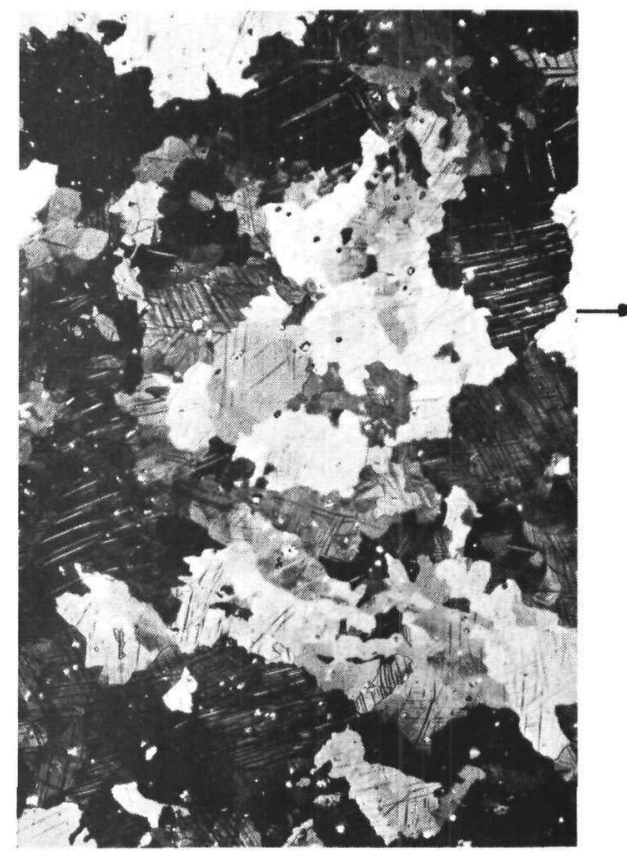

$26090--A N L-106-5185$

$75 \mathrm{X}$
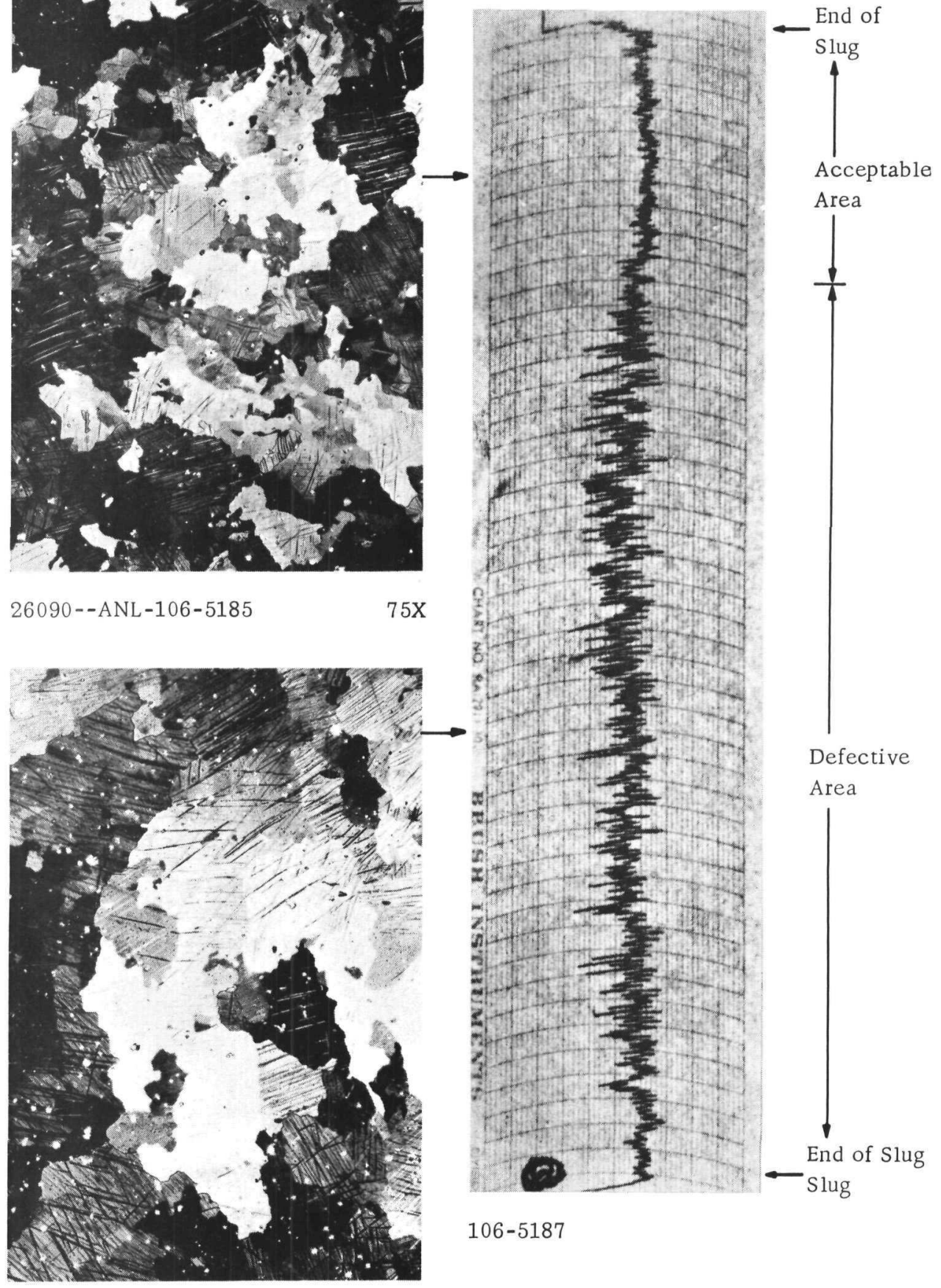

Acceptable

Area

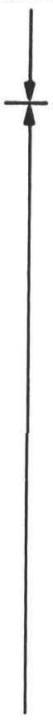

Defective

Area

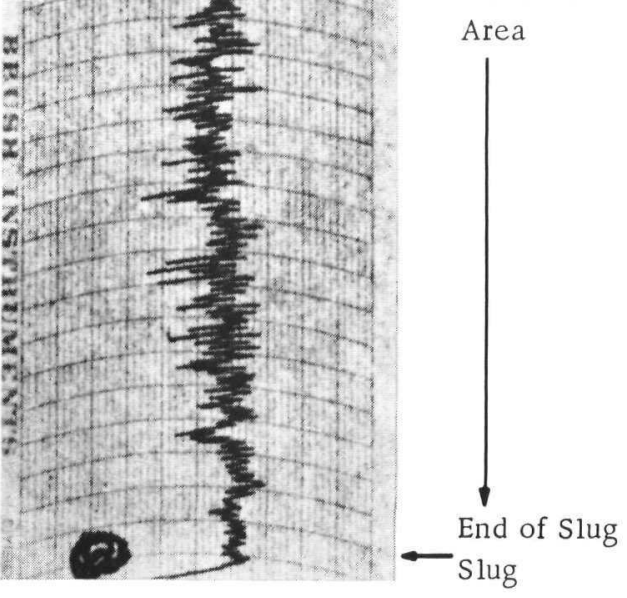

$106-5187$

$26092--$ ANL $-106-5186$

$75 X$

Fig. 6. Photograph of Ultrasonic, Through-transmission Trace and Photomicrographs of Corresponding Areas in EBR-II Small-diameter Production Blanket Slug. Large grain size typical of trace areas showing large oscillations. 
of its length. The large grain size results in wide fluctuations on the ultrasonic transmission test trace. Figure 7 shows a rod that has a very large grain size for approximately half the rod length where the material received a beta treatment, while the other half of the rod shows a very

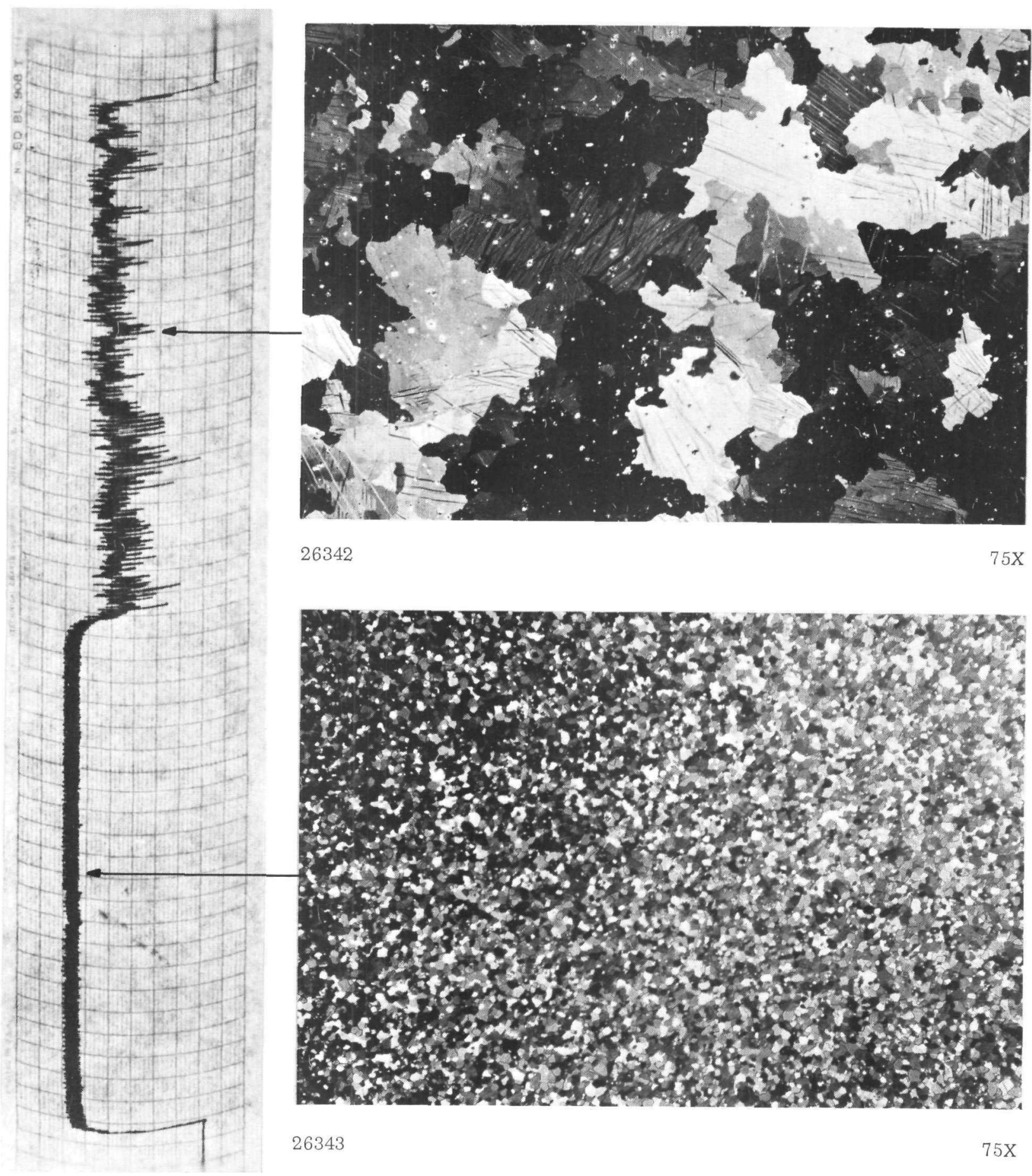

106-5004 (composite)

Fig. 7. Ultrasonic, Through-transmission Trace of Small-diameter Slug, Rejected for Abnormally Large Grain Size. Photomicrographs show area of large grain size and also an area of alpha-recrystallized material. 
fine-grained alpha-recrystallized structure. The effect of these structures on the ultrasonic trace is quite evident. X-ray diffraction studies on this rod showed a high degree of preferred orientation in the fine-grained area indicative of an as-rolled alpha structure, while the coarse-grained section exhibited considerably more random orientation, typical of beta-treated material. The effects shown on the ultrasonic trace due to large grain size (a wide fluctuation in trace width) and the presence of an as-rolled alpha structure (a displaced and very uniform trace) made it easy to distinguish material that had not received the proper beta heat treatment or material that possessed an abnormally large grain size. The as-rolled alpha structure occurred in sections of rolled rod stock that were not completely submerged in the salt bath during the beta heat treatment.

A total of 16,050 small-diameter slugs were received from National Lead; 16,047 were inspected and three were used for evaluation purposes before testing. Considering overall inspection results, 13,895 (86.6\%) of the slugs inspected were acceptable, 1,827 (11.4\%) were rejected for surface pitting or machining marks, and 325 (2.0\%) were rejected for defects found in ultrasonic testing. Initially, the visual rejects were not tested by ultrasonics. Later, 1,309 of these visual-reject slugs were ultrasonically tested, and 1,229 (94.0\%) were acceptable. Of the 15,529 slugs receiving the ultrasonic test, $405(2.6 \%)$ were rejected. The primary reason for rejection in ultrasonic testing was abnormal grain size.

Of the 95,593 large-diameter inner and outer blanket slugs received, 94,676 slugs were inspected; 80,742 (85.3\%) were approved for blanket loading, $10,776(11.4 \%)$ were rejected in the ultrasonic test, and 3,158(3.3\%) were rejected in the visual examination. The visual-reject group was eventually sonic-tested, and $2,765(87.6 \%)$ were acceptable, $393(12.4 \%)$ also being sonic rejects.

\section{ACKNOW LEDGMENTS}

The authors wish to thank J. F. Schumar and R. E. Macherey for their overall guidance of the work, W. N. Beck for the thermal cycling data, and R. H. Selner for establishing the ultrasonic testing conditions. The personnel of the Foundry and Fabrication Group deserve thanks for their efforts in final inspection of the slugs.

Special thanks go to C. W. Loveland and the personnel at Union Carbide Corp. for the production of the ingots, and to C. E. Bussert and many others at the National Lead Company of Ohio for the production of the finished slugs. Both phases were done well and with excellent cooperation. 


\section{REFERENCES}

1. J. C. Hesson, M. J. Feldman, and L. Burris, Description and Proposed Operation of the Fuel Cycle Facility for the Second Experimental Breeder Reactor (EBR-II), ANL-6605 (April 1963).

2. L. F. Koch et al., Hazard Summary Report Experimental Breeder Reactor II (EBR- $\overline{\mathrm{II}}$ ), $\overline{\mathrm{ANL}}-5719$ (May 1957).

3. R. L. Salley and C. H. Bean, Assembly, Sodium Bonding, and Inspection of EBR-II Blanket Rods, ANL-6418 (to be published).

4. W. D. Wilkinson, Uranium Metallurgy (Vol. 1), pp. 165-254, 1962. (Interscience, New York).

5. F. G. Foote, Physical Metallurgy of Uranium, Nuclear Metallurgy Symposium, AIME (Oct 1955).

6. S. T. Zegler, R. M. Mayfield, and M. H. Mueller, Effects of Fabrication and Heat Treatment Variables upon the Thermal Cycling Behavior of Uranium (presented at 29th ASM Soc. meeting, Nov. 4-8, 1957, in Chicago). 